\title{
Análise Documental Ilustrada em Administração Pública: uma Proposta Operacional (Re)Aplicável
}

\section{Illustrated Documentary Analysis in Public Administration: a (Re)Applicable Opera- tional Proposal}

\author{
Jorge Leal da Silva \\ Universidade Federal de Viçosa - UFV - Brasil \\ jorge.leal@ufv.br \\ ORCID: 0000-0003-0982-1924 \\ Magnus Luiz Emmendoerfer \\ Universidade Federal de Viçosa - UFV - Brasil \\ magnus@ufv.br \\ ORCID: 0000-0002-4264-8644 \\ Nina Rosa da Silveira Cunha \\ Universidade Federal de Viçosa - UFV - Brasil \\ ninarosaufv@gmail.com \\ ORCID: 0000-0002-2292-2159
}

Submetido em 23/03/2020; Aprovado em 20/07/2020.

\section{Resumo}

Objetivo: 0 necessário rigor metodológico na consecução da pesquisa documental apresenta-se como desafio para a qualidade na pesquisa social. Tomando como ponto de partida este problema, o presente artigo teve por objetivo propor a organização de procedimentos para a consecução da pesquisa documental na área de Administração Pública, no intuito de que, ao traçar ações ordenadas, aperfeiçoamentos na prática da pesquisa possam ser qualitativamente perceptíveis. Metodologia: Em termos metodológicos, empregou-se o estudo de casos ilustrativos, cuja inspiração se fundamentou na Design Science Research (DSR). Ao partir da organização de procedimentos propostos, aplicou-se a pesquisa documental, utilizando-se como ilustração um decreto presidencial para tratar da operacionalização do conceito de ética no serviço público federal brasileiro. Principais resultados: Com efeito, sinalizações em termos de condicionantes e procedimentos foram apontadas como contribuições para pesquisadores e práticos da área. Contribuição prática: a sistematização operacional proposta em fases apresenta-se como um contributo original e potencialmente reaplicável, quando se pretende extrair informações de documentos úteis a gestores e pesquisadores de organizações públicas.

Palavras-chave: Análise Documental Ilustrada; Administração Pública; Ética; Serviço Público Federal

\section{Abstract}

Objective: The necessary methodological rigor in the achievement of documentary research presents itself as a challenge for quality in social research. Taking this problem as a starting point, the present article aimed to propose the organization of procedures for the accomplishment of documentary research in the area of Public Administration, in order that, when drawing up ordered actions, improvements in research practice can be qualitatively noticeable. Methodology: In methodological terms, the study of illustrative cases was used, whose inspiration was based on Design Science Research (DSR). Starting from the organization of the proposed procedures, documentary research was applied using a presidential decree to illustrate the operationalization of the concept of ethics in the Brazilian federal public service. Main results: indeed, signs in terms of conditions and procedures were pointed out as contributions for researchers and practitioners in the area. Practical contribution: the operational systematization proposed in phases presents itself as an original and potentially reapplicable contribution, 
when it is intended to extract information from documents useful to managers and researchers from public organizations.

Keywords: Illustrated Document Analysis; Public administration; Ethic; Federal Public Service.

\section{Introdução}

Desde 1986 discute-se a incipiência da utilização da pesquisa documental em diversas áreas do conhecimento (Cunha, Yokomizo, \& Bonacim, 2014; Lüdke \& André, 1986). As fragilidades referiam-se à subjetividade das interpretações e das afirmações tecidas em artigos, livros, trabalhos de conclusão de curso, estudos de caso oriundos de especializações latu sensu, dissertações ou até mesmo de teses de doutorado (Moraes, Almeida, \& Alves, 2020).

O não esclarecimento do percurso metodológico adotado, a não identificação e caracterização dos documentos, a falta de confiabilidade das fontes documentais consultadas, a não clareza do tratamento e da construção empregada no corpus da pesquisa ou até mesmo a falta de preparo do pesquisador em compreender a estrutura de documentos são algumas das razões que explicam o porquê de a pesquisa documental ser objeto de constante aperfeiçoamento ou questionamento no que tange à necessidade do rigor científico em seus procedimentos (Cunha et al., 2014).

Embora não exclusivas da pesquisa documental, na área de Administração Pública (AP), pesquisas preocupadas em mitigar tais pontos de fragilidade têm sido incipientes. Tal aspecto se coloca como crítico e passível de discussão, sobretudo porque pode sofrer intervenção quando se utiliza o método, ainda que em apenas uma etapa da pesquisa qualitativa em Administração (Corrêa, Trottmann, Coelho \& Sarti, 2017; Garcia, Rodrigues, Emmendoerfer, \& Gava, 2016; Allegretti et al., 2018; Garcia, Pereira, Alcântara \& Prado, 2019; Silva, Costa, \& Nobre, 2014).

Não obstante, em situações de dúvida quanto à escolha do procedimento metodológico e das técnicas de pesquisa a se aplicar, é por meio de procedimentos rigorosos que pontos frágeis da pesquisa documental são minimizados, gerando, por consequência, segurança e confiabilidade em sua consecução como um todo (Flick, 2009). Nesse contínuo, com a consolidação da internet, os documentos têm constituído profícuo banco de dados, tornando-se matéria-prima não só para profissionais da área de AP propriamente dita, mas também para estudantes, docentes e pesquisadores interessados em explorar aspectos intra e interorganizacionais (Salminen, Lyytikäinen, \& Tiitinen, 2000), possibilitando ao sujeito pesquisador situar os fenômenos administrativos no tempo e no espaço (Costa \& Silva, 2019).

Sendo assim, em se tratando das dinâmicas inerentes ao modus operandi da AP brasileira, destacase que esta se expressa necessariamente por documentos das mais variadas espécies, formas, formatos, tipos, gêneros e suportes (Gonçalves, 1998). Um clássico exemplo dessa expressão são os decretos emanados pelo Poder Executivo, que são submetidos ao Processo Legislativo Federal e contam com a participação de representantes eleitos pela sociedade em seu processo de elaboração (Vieira, 2018).

Neste caso, para além dos atores institucionais dados legitimamente pela realidade, seu processo de produção textual conta com o auxílio de atores que, embora submersos no contexto da produção documental, têm papel fundamental na disseminação de ideias e de defesas técnico-científicas nesse processo, como, por exemplo, pesquisadores e docentes experientes em determinados assuntos (Bowen, 2009; Cunha et al., 2014; Morris \& Ecclesfield, 2011).

Em paralelo, ao passo que a internet ampliou a gama de possibilidades para pesquisa em ciências sociais aplicadas, trouxe, em intensidade similar, desafios quanto à assertiva escolha de dados e informações que produzam sentido coerente nas produções científicas, sendo o trabalho de curadoria de documentos, atividade central na coleta, guarda e distribuição de documentos (Bax \& Resende, 2020). Suscitam-se, assim, novos cuidados a serem tomados por pesquisadores, como, por exemplo, a garantia de que dado documento corresponda e narre os fatos como eles ocorreram ou ocorrem na realidade e de que o autor informado no documento corresponda em verdade àquele responsável por sua produção. Tais elementos, se esclarecidos, contribuem com o rigor da pesquisa qualitativa em AP.

Por essa razão, compreender o documento enquanto objeto de construção social conduz o pesquisador a assumir uma atuação crítica e reflexiva quanto à elegibilidade das fontes de pesquisa, bem como às suas implicações no resultado final. Sob esse aspecto, a pesquisa documental não se reduziria a simples constatações de elementos e fatos sociais para se construir textos meramente descritivos e narrativos. Pelo contrário, seu potencial envereda-se para aspectos complexos da produção textual humana 
(Costa \& Silva, 2019; Sá-Silva, Almeida, \& Guindani, 2009). Destarte, ante o rigor científico não pleno quando da realização da pesquisa documental na área de AP (Schultz, 2018), como sistematizar a operacionalização da pesquisa documental em fases coerentes e concatenadas?

Destaca-se que a não plenitude do rigor metodológico não só se coloca como o problema organizacional em exame, como também constitui discussão pertinente, pois, para se construir uma teia de argumentos cientificamente validáveis e, por óbvio, verificáveis e replicáveis por outros pesquisadores, o rigor metodológico é condição sine qua non. Os fatos mencionados, as informações sintetizadas e as inferências e interpretações empregadas na pesquisa documental precisam não só se situar teoricamente, como também devem se alinhar com o corpus construído durante a pesquisa e com a busca por referências bibliográficas para fundamentar afirmações (Cellard, 2008).

Este artigo tem por objetivo propor a organização de procedimentos para a pesquisa documental na área de Administração Pública, com vistas a atingir adequado rigor metodológico. Embora a pesquisa documental tenha utilidade e aplicabilidade multidisciplinar e transversal, este artigo não intenciona indicar diferenças ontológicas ou epistemológicas entre as diferentes áreas do conhecimento, tampouco pretende prescrever um manual determinístico e rígido. A área de saúde pública, por exemplo, apresenta demanda por procedimentos sistemáticos para o uso da pesquisa documental, considerada complexa e demorada por práticos da área (Tete, 2020), sinalizando, assim, uma necessária aproximação da Ciência da Informação (CI) com diferentes áreas de atuação do poder público (Nunes, Simeão \& Pereira, 2020). Contudo, considera-se possível que a organização de procedimentos para a pesquisa documental seja (re)aplicável para áreas como a CI. A aproximação do conteúdo deste artigo com essa área em específico não se deve somente ao seu caráter interdisciplinar, mas também ao seu intuito de prover e manter a verdade quando se pretende eleger e gerir informações condizentes com os fatos sociais (Moraes et al., 2020).

Logo, em termos de delimitação deste estudo, destaca-se que, ao discutir o rigor metodológico na pesquisa em AP, torna-se imprescindível considerar e explorar a interdisciplinaridade com a CI, sobretudo quando se considera que o objetivo da pesquisa documental explorado por este artigo é a construção de informações confiáveis (Cellard, 2008; Flick, 2009) para a AP, tomando como exemplo o estudo de Hepworth (2014) e Almeida (2015). Demonstra-se, assim, esse imperativo, que é traduzido, respectivamente, em competências necessárias ao pesquisador e a usuários de sistemas de informações no nível federal.

\section{Revisão teórica de aspectos conceituais da pesquisa documental no contexto e realidade da Administração Pública (AP)}

Antes de evidenciar os pormenores dos procedimentos da pesquisa documental, cumpre, além de conceituá-la, também explanar o que constitui um documento passível de incorporação na construção de corpus de pesquisas na área de AP. Nesse limiar, recorreu-se à área de Arquivologia para compreender as classificações técnicas empregadas na gestão de documentos.

Nessa tarefa, cumpre distinguir forma de formato. A primeira "é o estágio de preparação ou transmissão do documento", podendo apresentar-se na forma original, cópia, minuta e/ou rascunho. Já o formato é a "configuração física de um suporte, de acordo com a natureza e o modo como foi confeccionado", por exemplo, cadernos, cartazes, diapositivos, e-books, folhas, livros, mapas, plantas, rolos de filme, dentre outros (Gonçalves, 1998, p. 17; Cellard, 2008).

Sem exceção, todo documento produzido é transformado em um suporte constituído pelo próprio material sobre o qual as informações são registradas, tais como a fita magnética, filme de nitrato ou, por óbvio e mais popular, o papel, e também recentemente suportes digitais. 0 gênero do documento é a configuração de materiais em função do conteúdo que carregam, como, por exemplo, a documentação audiovisual, fonográfica, iconográfica e textual. A espécie se refere estritamente a como esse conteúdo se configura no documento, podendo ser um boletim, certidão, declaração ou relatório (Gonçalves, 1998). Há diversos tipos de documentos(Quadro 1), tais como boletim de ocorrência, de frequência, de rendimento escolar etc.; no caso de certidões, tem-se as de casamento, óbito etc.; já as declarações podem ser de bens, de imposto de renda etc.; enquanto os relatórios podem ser de atividades, de fiscalização, dentre outros.

Enfim, documentos decorrentes de atividades específicas geram diferentes tipologias textuais em função do fato gerador (Simão \& Rodrigues, 2006). Os documentos são entendidos como tudo aquilo 
que é vestígio do passado e é captado, percebido e transposto em matéria - comumente o papel - e pode, por consequência, ser utilizado como testemunho do processo de construção dialética e social dos fenômenos sociais (Cellard, 2008). Documentos públicos são práticas discursivas que se caracterizam por interanimações dialógicas variadas, sendo fundamentais para a formulação e manutenção de estratégias de governo (Bernardes \& Menegon, 2007), cuja essência se refere ao controle exercido sobre a massa populacional.

Quadro 1 - Tipos e descrições de documentos

\begin{tabular}{ll}
\hline Tipo & Descrição \\
\hline Boletim de ocorrência & Narrativa de diligências \\
Frequência escolar & Planilha de divulgação de presença de aluno \\
Certidão de casamento & Documento lavrado em cartório que une juridicamente pessoas físicas \\
Certidão de óbito & Documento informativo de motivos determinantes sobre causa de morte \\
Declaração de bens & Documento informativo da quantidade de valores e patrimônio pessoal ou empresarial \\
$\begin{array}{l}\text { Declaração de imposto de } \\
\text { renda }\end{array}$ & $\begin{array}{l}\text { Documento entregue à Receita Federal do Brasil informando rendimentos pessoais ou empre- } \\
\text { Relatório de atividades }\end{array}$ \\
\hline
\end{tabular}

Fonte: Elaborado pelos autores com base em Simão e Rodrigues (2006).

Ao empregar busca sobre como os procedimentos da pesquisa documental têm sido adotados em teses e dissertações brasileiras, observou-se que as principais justificativas em utilizá-la têm sido a necessidade de se reconstituir o passado (Silva, 2017) ou de analisar o objeto de estudo sob a perspectiva sócio-histórica (Cavalcanti, 1995). Já nos estudos de Carvalho (2018), Bezerra (2011) e Amorim (1994), a despeito de os documentos não terem sido o cerne da análise, serviram de meios para tecer contribuições na área de AP.

Ante o exposto, é preciso demarcar que, embora a pesquisa documental tenha certa aderência e uso por pesquisadores em diversas áreas do conhecimento, com base em Costa \& Silva (2019), é perceptível que, na área de Administração, a consecução deste tipo de pesquisa envereda-se por, pelo menos, três perspectivas, quais sejam: a suplementarista, a integracionista e a reorientacionista.

A suplementarista se refere ao tradicional esforço de se compreender os documentos como fonte única e exclusiva de uma construção narrativa dos fatos sociais, que podem ser pensados e integrados de modo suplementar à compreensão do cotidiano organizacional - ou melhor, do contexto históricoorganizacional. Já a perspectiva integracionista postula que os esforços de pesquisa documental devem ter caráter interdisciplinar, de modo que não restrinjam o potencial contributivo dos documentos em áreas exclusivas, como a da história (Costa, Barros, \& Martins, 2010). Na perspectiva reorientacionista, seu tom crítico pontua que a prioridade em termos de escolha teórico-metodológica deve pairar no âmbito da historicidade por meio da narrativa dos fatos, porém com alinhamento aos interesses interpretativos e discursivos, opostos à mera descrição e narrativa simplória do ocorrido no passado (Costa et al., 2010).

O marco inicial e o valor da Design Science Research (DSR) consiste no exercício do "contexto de descoberta", conforme afirmado pelo filósofo Hans Reichenbach, que é o contexto no qual o pesquisador faz uma investigação inicial, com profundos conhecimentos teóricos e empíricos, no esforço de obter um frame de intervenção ou tratamento de um problema social com potencial descoberta científica (Reichenbach, 1938). Aproxima-se, pois, de um modo pós-moderno de fazer ciência, rompendo com o preconceito instintivo de positivistas sobre o Design enquanto uma pseudociência (Phillips, 2006; Hevner, 2007).

A investigação é um processo criativo, porém disciplinado. A DSR explora o oportunismo de ideias e as sistematiza, trazendo um grau de racionalização a um processo de pesquisa, permitindo sua reaplicabilidade. Em DSR, os testes em "pequena escala" não devem ser acusados de incipientes e de exercícios iniciais assumindo um significado de imaturidade e de qualidade inferior, pois um teste de hipóteses "amplo" não é condição sine qua non na DSR (Phillips, 2006). Permite-se, deste modo, testes em pequena escala - que, de acordo com Dewey (1971) e Popper (1974), resultarão na construção de modelos convincentes - independentemente de haver ampla validação de imediato.

Embora a dificuldade da DSR seja a de estabelecer um padrão de ouro para controlar variáveis, a 
busca por esse padrão não deve ser relegada exclusivamente ao pesquisador, mas sim ao modo de fazer DSR propriamente dito. No entanto, isso não significa que a análise de qualidade de uma DSR não possa ser realizada, pois, no que tange à responsabilidade do pesquisador, há três critérios mínimos de qualidade a se observar (Phillips, 2006). 0 primeiro deles é estabelecer com precisão o que se pretende alcançar com a DSR, podendo esta: a) contribuir para o processo de pesquisa; b) lançar luz sobre uma pedagogia do design; e/ou c) criar um programa tecnicamente inovador (Wieringa, 2014; Hevner, 2007; Phillips, 2006). Já o segundo critério consiste na explanação de como os objetivos da DSR foram alcançados. 0 terceiro é o know-how do pesquisador ou dos pesquisadores responsáveis pela DSR, cuja finalidade é assegurar a profundidade do conhecimento empírico e teórico a se gerar com os resultados de pesquisa (Hevner, 2007).

Contudo, para a concepção dos passos componentes de fases para a Análise Documental Ilustrada (ADI), a principal fonte inspiradora consistiu no capítulo "Análise Documental" escrito por André Cellard e disponível no livro "A pesquisa qualitativa: enfoques epistemológicos e metodológicos", organizado por Jean Poupart em 2008, que traz cuidados a serem levados em consideração pelo pesquisador na prática da pesquisa documental. Quanto à concepção ilustrativa, esta não só partiu do caráter pedagógico cunhado por Ikeda, Veludo-de-Oliveira e Campomar (2005) e Phillips (2006), como também ganhou força com a identificação de pesquisas aquém de rigor metodológico na área de AP, constatação possível através da disciplina "Métodos Qualitativos Aplicados às Ciências Sociais" do Programa de Pósgraduação em Administração (área de concentração em Administração Pública) strictu sensu da Universidade Federal de Viçosa, Minas Gerais, Brasil. Destarte, possibilitado pela DSR, este artigo se lançou na propositura e validação (por meio de um caso ilustrativo) de fases para uma Análise Documental Ilustrada (ADI).

\subsection{Propondo fases para a Análise Documental Ilustrada (ADI)}

Independentemente da escolha metodológica que o pesquisador faça, é de fundamental importância estabelecer previamente não só o objeto, como também a(s) questão(es) e os objetivos da pesquisa, para que estes se alinhem com o percurso metodológico. Nesse caminho, antes de iniciar a análise documental propriamente dita, observa-se que pelo menos duas fases são sistematizadas, conforme propõe a Figura 1.

Figura 1. Fases da Pesquisa Documental

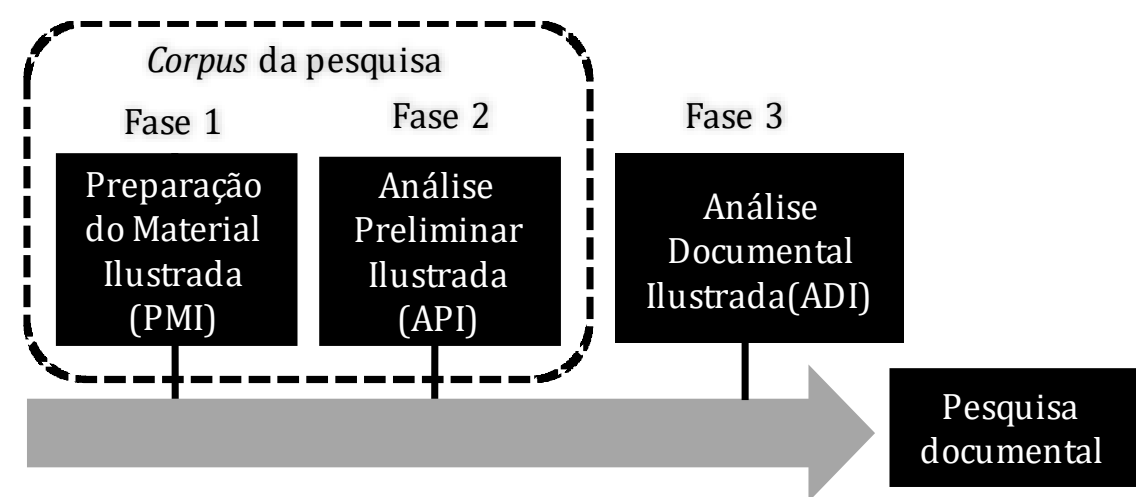

Fonte: Elaborada pelos autores.

Em relação à preparação do material, fase 1 da pesquisa documental, há cuidados a se tomar, a começar pelo reconhecimento de fontes potenciais de informação, o estabelecimento de critérios de busca e classificação de documentos, a certeza de que as consultas foram de fato exaustivas, a flexibilidade a se considerar, a localização de textos pertinentes e a avaliação não só da credibilidade, como também da representatividade dos textos, além da compreensão do sentido da mensagem (Cellard, 2008; Lemos \& Souza, 2019).

Porém, para que os referidos esforços possam ser empregados sem gerar confusão durante esse momento da pesquisa, a Figura 2 organiza-os sistematicamente. 
Figura 2 - Fase 1: Preparação do Material Ilustrada (PMI)

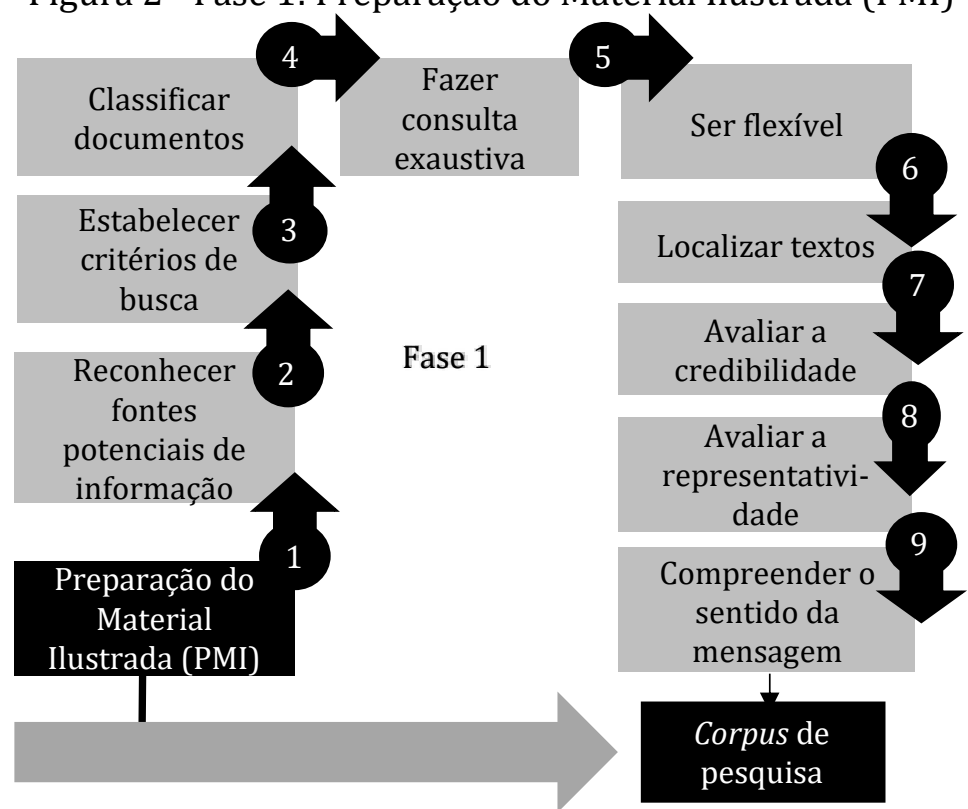

Fonte: Elaborada pelos autores.

Embora as atividades supracitadas exijam tempo e minucioso exame por parte do pesquisador, cumpre ressaltar que a construção do corpus da pesquisa até então não é suficiente para uma robusta análise documental. É preciso incorporar outros elementos a esse processo, conforme evidencia a Figura 3.

Figura 3 - Fase 2: Análise Preliminar Ilustrada (API)

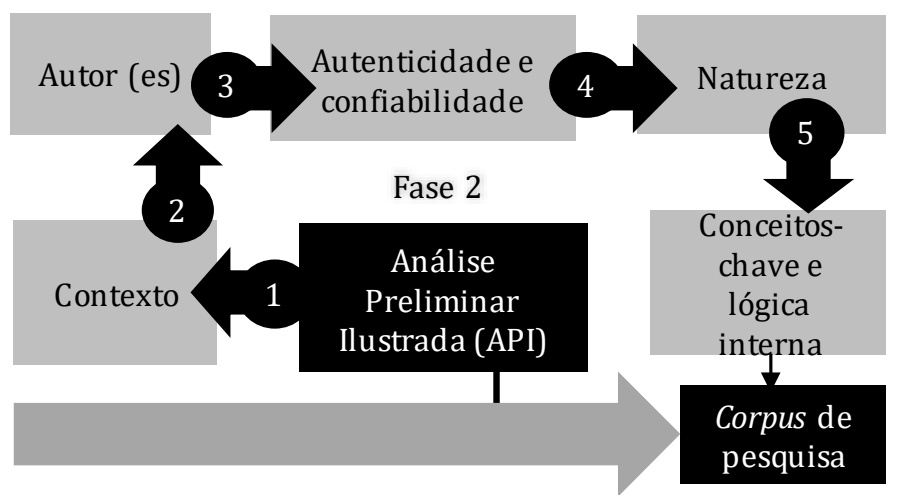

Fonte: Elaborada pelos autores.

A análise preliminar ilustrada dos documentos não se confunde com a análise documental. A diferença está no grau de profundidade empregado na leitura dos documentos componentes do corpus da pesquisa. Nesse momento, a leitura dirigida e alinhada aos objetivos e questões de pesquisa permite que o pesquisador não se perca no percurso metodológico. Evita-se, pois, que maiores esforços de leitura e análise de documentos sejam realizados em desacordo com o foco do estudo.

Nesse sentido, a leitura dirigida permite analisar o contexto e os autores envolvidos nessa produção, bem como a autenticidade e a confiabilidade, a natureza, os conceitos-chave e a lógica interna dos documentos (Cellard, 2008). Em relação ao contexto, ressalta-se que este não se confunde com a análise da conjectura, ainda que preliminar. Essa distinção é importante para os efeitos deste artigo, pois os relatos sobre o contexto se distanciam do objetivo de traçar a possibilidade de ocorrência de eventos futuros, ou seja, uma suposição. A previsibilidade dos fatos constitui, em essência, o objeto da análise conjectural, o que extrapola os objetivos deste estudo. Já a dimensão do contexto se refere ao que de fato ocorre no mundo real de modo relacional (Cunha et al., 2014), uma vez que a "[...] informação não está no objeto, mas no contexto que possibilita a informação" (Moraes et al., 2020, p. 15). 
A observação do contexto social ou a entrevista com membros participantes do processo de produção textual é fundamental para assegurar o rigor do processo de pesquisa, sobretudo quando se busca validar e oferecer maior profundidade de sentidos às informações coletadas pelos documentos. Neste esforço, é preciso tomar cuidado para que, na fase 3 - Análise Documental Ilustrada (ADI) -, inferências e interpretações não adquiram tom meramente descritivo e narrativo, conforme sinalizam Costa e Silva (2019).

Essa preocupação com o contexto consta também nos estudos de Costa e Silva (2019), que colocam o anacronismo como elemento crítico de pesquisas documentais não rigorosas. Outro importante ponto é que afirmações determinísticas não sinalizam uma pesquisa documental rigorosa, pois, se assim o fosse, levantar-se-ia maior margem para questionamentos na comunidade acadêmica. Em termos de autenticidade, e decorrente da confiabilidade do documento, esta refere-se à qualidade do conteúdo documental livre de adulteração ou de qualquer outro meio de corrupção que gere dúvida quanto à real correspondência entre o narrado e o ocorrido, ou seja, não se resume a instrumentos jurídicos (Conselho Nacional de Arquivos, 2014).

Figura 4 - Fase 3 da Análise Documental Ilustrada (ADI)

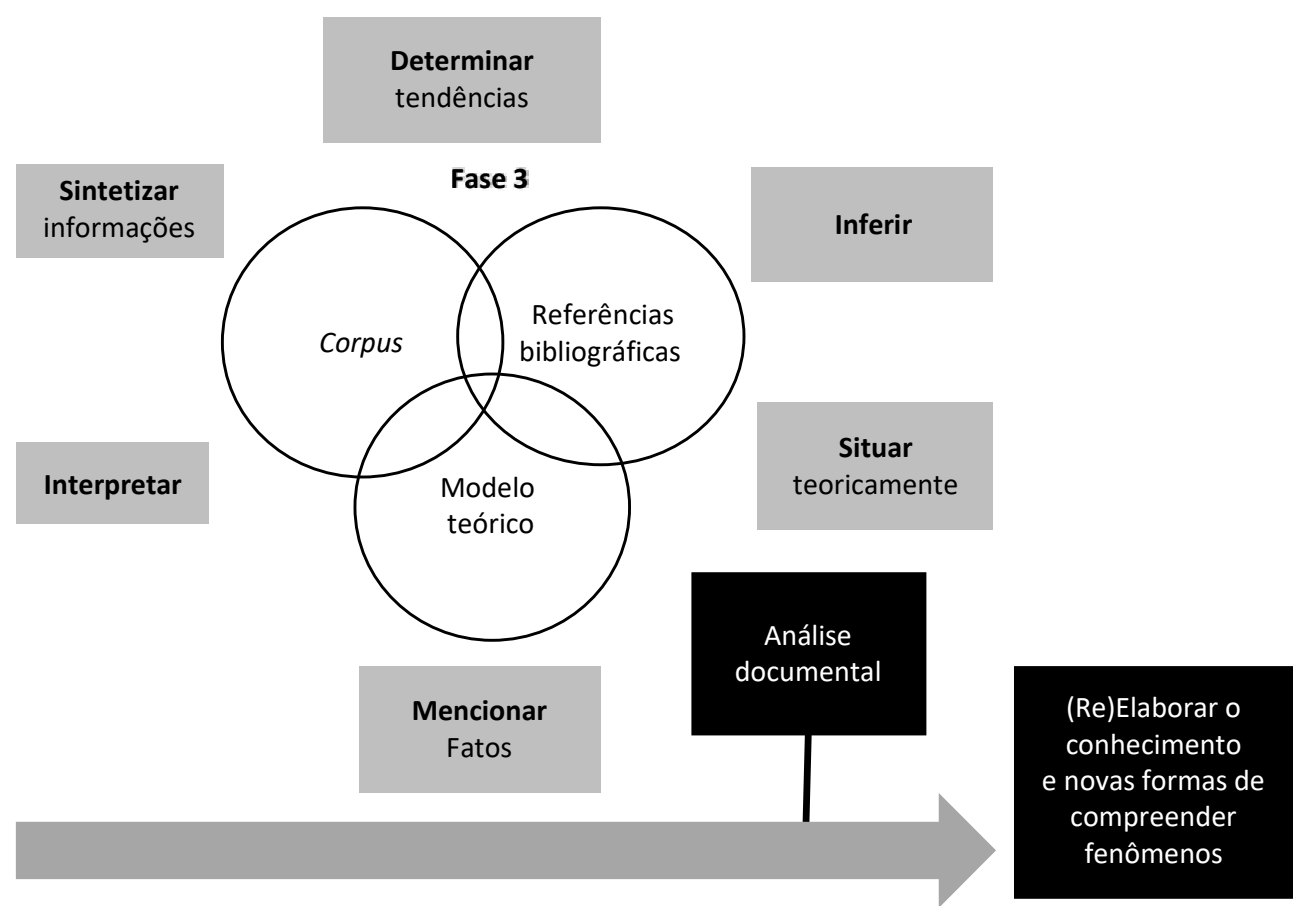

Fonte: Elaborada pelos autores.

Na Etapa 3, para que se possa determinar tendências, inferir e situar teoricamente os argumentos, é preciso traçar uma teia de argumentos coerentes e concisos para que o mencionar fatos, o interpretar dados e o transformá-los em informações possam ser coerentes e passíveis de validação.

\section{Metodologia de pesquisa}

0 desenvolvimento da pesquisa se inspirou no método de estudo de caso ilustrativo, empregado em Ikeda, Veludo-de-Oliveira e Campomar (2005), por três principais razões. A primeira razão é que, ao descrever de modo ilustrado um evento ou processo, o referido método estimula a compreensão dos aspectos processuais e atua, dessa forma, de modo pedagógico. Essa inspiração didática se mostra pertinente para o objetivo do presente artigo por corroborar com a Análise Documental Ilustrada (ADI) a ser aplicada no mundo real, e ter, por consequência, melhoria no seu rigor. A segunda razão é que, quando há dificuldade de operacionalização de algum conceito ou modelo, para Ikeda, Veludo-de-Oliveira e Campomar (2005), a utilização de casos se faz pertinente, pois extrai de situações reflexões com potencial resolutivo para criticidades identificadas. Já a terceira razão se explica por contemplar que a quantidade de informações disponíveis quando da escolha do caso ilustrativo é de moderada para alta. Devido a isso, ainda que classificadas como um caso ilustrativo, as discussões tecidas se referem ao 
mundo real, justamente por se utilizar de documentos e teorias que, em verdade, existem.

Nesse limiar, os autores cunham quatro parâmetros a se considerar na utilização do método de caso de modo geral, a saber: a finalidade pedagógica, a disponibilidade de informações, o nível de estruturação e de complexidade. Em termos de finalidade pedagógica, esta se explica pela própria intencionalidade de desenvolvimento deste artigo, que, para atingir seu objetivo, elegeu um decreto presiden-

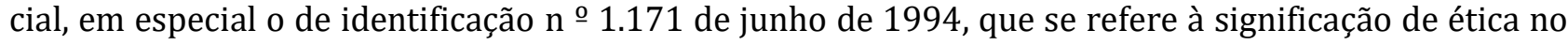
serviço público federal. Os critérios de elegibilidade documental foram: a) fazer menção ao termo "ética"; b) direcionar-se a servidores públicos em nível "federal"; c) situar-se temporalmente entre 1990 e 2010. Logo, a escolha pelo Decreto $\mathrm{n}$ o 1.171 de junho de 1994 justifica-se em razão de ser o primeiro decreto presidencial a dispor sobre o tema.

A intenção é demonstrar a aplicabilidade dos procedimentos ensaiados na seção anterior, bem como encontrar possíveis pontos de melhoria na consecução da pesquisa documental. Outros documentos podem ser selecionados para o exame do caso em tela, porém, devido ao limitado espaço em que se inscreve este artigo, optou-se por utilizar apenas um documento com o qual os autores tiveram contato prévio. Isso reforça Ikeda et al. (2005, p.150) quando da explicação de que "os casos, ainda, podem ser escritos com base na própria experiência do autor", justificando e atendendo, assim, o critério knowhow de qualidade na DSR ressaltado por Phillips (2006).

A utilidade deste trabalho reside no caráter de "como as coisas deveriam ser" do método DSR. Isso significa que a inspiração e expectativa quanto à pedagogia e à validade externa esperada (Dresch, Lacerda \& Antunes Junior, 2015), a partir das fases para a ADI aqui propostas, possam ser perceptíveis e adaptadas a diferentes recortes de pesquisa e, assim, colocadas em prática.

Antes de aplicar na prática os procedimentos da ADI, cumpre esclarecer informações basilares, tais como o conceito de ética e os fundamentos teóricos a se considerar na presente análise. Esse esclarecimento atende ao parâmetro da disponibilidade de informações a se considerar na operacionalização da pesquisa de casos ilustrativos. Destarte, a ética será entendida como o estudo do comportamento humano ou como qualquer investigação sobre o que é bom e o que é mau, e o modo pelo qual as normas foram histórica e teoricamente validadas e estabelecidas para todos (Assmann, 2012).

Esse conceito de ética remete à teoria relativista, que, grosso modo, sublinha que cada pessoa deveria decidir sobre o bem e o mal, de modo que, nesse contexto, consta o elemento ético, que é inerentemente relativo, pois o que para alguns pode ser bom ou mau, para outros pode não ser considerado do ponto de vista ético (Cremaschi, 2007).

Nesse sentido, outras três teorias também servem de fundamentos para a análise, quais sejam: a teoria Contratualista, Kantiana e a Consequencialista. Na teoria Contratualista, o sujeito deve se comportar de acordo com as regras morais expressas e "contratualizadas" para que, assim, possa se viver em sociedade. Em essência, fundamenta-se no conhecimento filosófico oriundo dos contratualistas JeanJacques Rousseau, Thomas Hobbes e John Locke (Nascimento, 2011). Já a teoria Kantiana postula que a força jurídica de códigos de ética, ao ser imperativos e, logo, postos aos sujeitos, possibilita que comportamentos alheios ao ideal a ser perseguido sejam repreendidos, e que, por consequência, tenha-se um certo padrão operativo da ética. Em outras palavras, esse mecanismo é colocado como sendo categórico porque tal obrigação não está dependente de quaisquer desejos de uma pessoa (Kant, 2006). Em relação à teoria Consequencialista, interessa observar que toda ação humana em conjunto é justificável sob a ideia de que, ao agir em consenso, gerar-se-á, por consequência, o bem para a sociedade como um todo.

Recorrendo aos preceitos de Foucault específicos para a gestão de pessoas, sua terceira fase de estudos sobre ética concebe os sujeitos não apenas como ativos, mas como autoformativos. Ou seja, a faculdade das individualidades é a responsável por definir o modo com que cada servidor público se relaciona com ordens emanadas por agentes de poder (Miranda, 2014), ou seja, neste caso ilustrativo, um decreto "disciplinador" emanado pelo Presidente da República. A centralidade do conceito de autoformação em gestão de pessoas consiste na sua instrumentalidade, servindo como uma técnica disponível a gestores públicos e políticos que tenham por objetivo o estabelecimento da coesão e do padrão comportamental das burocracias (Aquino, 2019). Destarte, foram elaborados os Quadros 2 e 3 com os significados e comparações acerca do conceito de ética, respectivamente. 
Quadro 2 - Significados de ética

\begin{tabular}{ll}
\hline Teoria & Significado de ética \\
\hline Relativista & A faculdade do sujeito que a define, podendo o bom e o mau serem relativos. \\
Contratualista & $\begin{array}{l}\text { Contrapõe-se à teoria relativista. Fixa-se em contratos tácitos demarcando o que é bom e o que é } \\
\text { mau. Apresenta variação em função da sociedade em exame. } \\
\text { Kantiana }\end{array}$ \\
$\begin{array}{l}\text { Como fim, fixa um padrão comportamental a ser buscado. Como meio, lança mão de códigos de ética, } \\
\text { de sua força jurídica. }\end{array}$ \\
$\begin{array}{l}\text { Fundamentando-se no consenso social, requer coesão interna e coesão externa suficientes para con- } \\
\text { vencer o coletivo de que um meio precisa ser utilizado para se alcançar o bem-estar social. }\end{array}$ \\
\hline
\end{tabular}

Fonte: Elaborado pelos autores.

0 contrato tácito (na forma de Decreto presidencial, por exemplo) não implica necessariamente na coesão interna e externa do comportamento coletivo, uma vez que este é formado por crenças e valores externos à organização. Significar afirmar que códigos de ética não garantem per si determinado padrão comportamental sem previamente haver consenso social de quais pressupostos são válidos e aceitáveis pela sociedade (Nascimentos, 2011). Por essa razão, conforme demonstrado no Quadro 3, o contrato tácito assenta-se sob os fundamentos da Teoria Contratualista.

Quadro 3 - Comparativo de significados de ética

\begin{tabular}{lcccc}
\hline Teoria & Relativista & Contratualista & Kantiana & Consequencialista \\
\hline Ética relativa & $\mathrm{X}$ & & & $\mathrm{X}$ \\
Ética não relativa & - & $\mathrm{X}$ & $\mathrm{X}$ \\
Contrato tácito & - & $\mathrm{X}$ & $\mathrm{X}$ \\
Código de ética & - & & $\mathrm{X}$ \\
Consenso & - & & \\
\hline
\end{tabular}

Fonte: Elaborado pelos autores.

Por fim, o nível de estruturação do caso ilustrativo ora em tela é de moderado para alto. Já em relação ao nível de complexidade, este atingiu o maior nível, pois, para se empregar de fato uma pesquisa documental robusta, raciocínio, reflexões e o domínio de conceitos e teorias se fizeram necessários. Assim, nessa esteira, evidencia-se hipoteticamente a seguinte questão de pesquisa a ser investigada por meio do caso ilustrativo: devido à incompreensão do conceito de ética por burocratas do Poder Executivo Federal, e sua consequente inoperância no âmbito da União, quais foram as ações implementadas pelo governo federal para reverter essa situação? Como diferentes interpretações do conceito de ética foram administradas pelo governo federal? Sendo assim, com vistas a operacionalizar a ADI nos termos ora desenhados, a próxima seção empregará esforços em conformidade com as etapas evidenciadas nas Figuras, 2, 3 e 4 .

\section{Resultados e discussão}

\subsection{Fase 1: Preparação do Material Ilustrada (PMI)}

Como resultado de pesquisa, a Figura 5 demonstra sistematicamente como o quadro dos passos seguidos para a preparação do material foi composto a partir do exercício de uma perceptiva ilustrada.

Em termos de reconhecimento de fontes potenciais de informação, é fundamental considerar que, para captar informações relevantes dos atos administrativos emanados pela administração pública brasileira, é preciso atentar-se que estes são não só registrados, como também disponibilizados para consulta on-line em portais oficiais do governo. De modo adicional, considerando que este estudo tem por enfoque o âmbito federal, não seria adequado pesquisar sobre o entendimento do conceito de ética em portais do governo do Estado e/ou municipal. Por essa razão, considerou-se como fonte o site "www4.planalto.gov.br", cujo portal reúne documentos de ação do governo federal.

Em continuidade, é preciso estabelecer critérios de busca nesse espaço virtual. Nesse sentido, ao inserir o termo "ética" em mecanismos no portal, identificaram-se inúmeros documentos, porém, em função dos recortes deste estudo, elegeu-se o Decreto n o 1.171 de 1994 (Brasil, 1994). Sua classificação enquanto documento é a seguinte: o gênero é textual; a espécie do ato administrativo é decreto; a tipologia é decreto presidencial; a forma é porta-original, pois foi consultada uma cópia cujo formato é o 
digital, sendo seu download realizado em arquivo no formato "PDF"; e a natureza do assunto é ostensiva, ou seja, sem restrição de visualização.

Figura 5 - Preparação do Material Ilustrada (PMI)

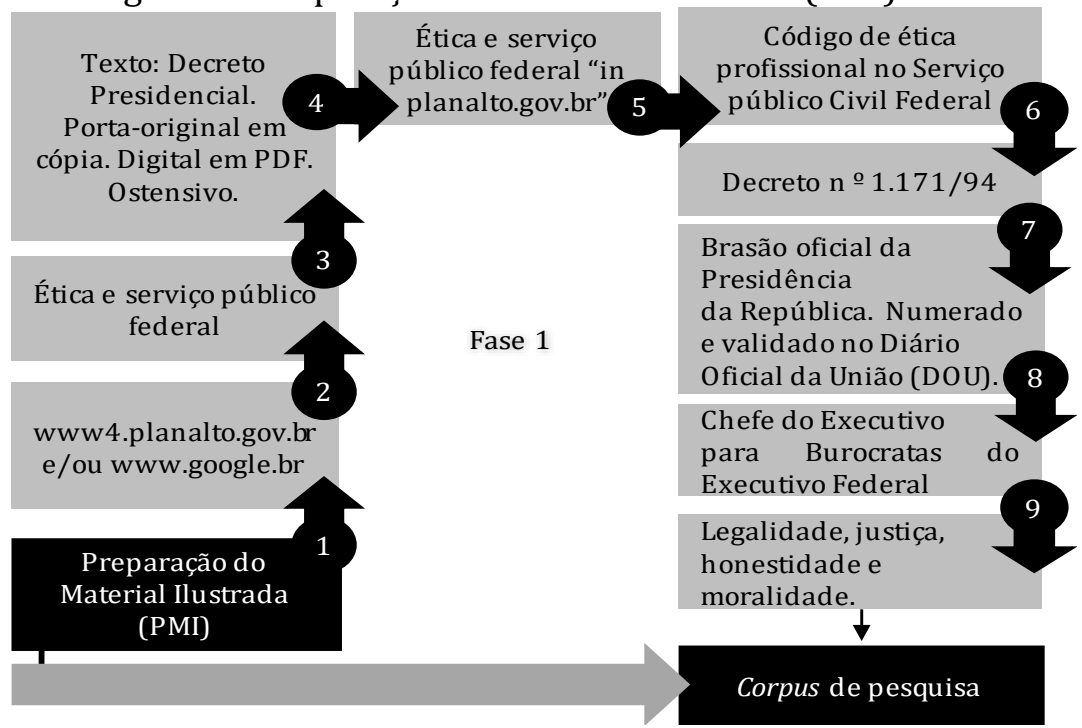

Fonte: Elaborada pelos autores.

Em relação a essa restrição, deve-se salientar que, quando se pretende ter acesso aos acervos privados presidenciais - que são gerenciados pela Presidência, Vice-Presidência da República e Casa Civil desde 1980 -, é provável que o pesquisador tenha seu acesso negado em virtude de que o Estado brasileiro "[...] carece de políticas mais efetivas relacionadas às formas de consulta e acesso aos acervos privados de presidentes da república, tendo em vista, inclusive, os conflitos entre os interesses individuais e coletivos" (Lopes \& Rodrigues, 2019, p.64 ). Para os autores, o acesso ao acervo privado presidencial possibilita ao pesquisador o conhecimento das causas que determinaram a promulgação de uma lei ou até mesmo um decreto (Lopes \& Rodrigues, 2019).

A necessidade de maior efetividade refere-se ao limite fático-probatório da Lei de Acesso à Infor-

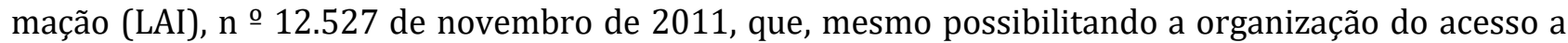
documentos, restringe-o a períodos específicos da história, sinalizando, pois, a atenção do pesquisador quanto a esses períodos. 0 período mais conhecido por essa restrição é o da ditadura militar, conforme destacado por Tenaglia e Rodrigues (2020) em pesquisa documental realizada. No entanto, embora a transparência dos atos de governo proporcionada pela LAI seja considerada a regra geral para Administração Pública, em análise aos modelos de disponibilização de dados do Instituto Brasileiro de Geografia e Estatística (IBGE), do Instituto Nacional de Estudos e Pesquisas Educacionais Anísio Teixeira (Inep) e do Instituto de Pesquisa Econômica Aplicada (Ipea) (principais fontes documentais em suas respectivas áreas), há ainda a ausência de legislação específica e a ausência de clareza e de precisão conceitual da LAI (Gonçalves \& Varella, 2018). Isso significa que especial atenção deve ser dada ao tipo de fonte documental demandada já em fases iniciais da pesquisa documental.

Quanto à certeza de que a consulta foi realmente exaustiva, pesquisas nos mecanismos de busca do Google foram empregadas considerando parâmetros como "ética in planalto.gov.br" de modo que se houvesse algum link quebrado e/ou resultado não constante nos próprios mecanismos de busca disponibilizados no portal, esse protocolo revelaria de modo mais ágil. A percepção e a atenção do pesquisador nesse momento são elementos viscerais para assegurar a exaustividade, sobretudo quando se obtiveram decretos emanados com menção à palavra "ética" nos anos de 1994, 1999, 2002, 2003, 2005 e 2008.

Outro protocolo interessante que pode ser incorporado nesse sentido é que, para além do próprio decreto presidencial, este, ao referenciar outros documentos utilizados - comumente legislações - em sua produção, oferece interessante e possível incorporação de novos documentos ao corpus da pesquisa. Em matéria de flexibilidade, cumpre considerar ainda que, ao se indexarem nos arquivos governamentais, os decretos portam palavras-chave que condensam, em essência, o conteúdo do documento. Sendo 
assim, ao localizar o documento em exame e observar tais palavras, identificaram-se que, em especial, "código de ética", "serviço público civil" e "qualidade do serviço público", apresentam potencial para compor novas palavras-chave a se considerar em buscas posteriores.

Quando se empregaram novas buscas considerando tais termos, outros documentos, como o próprio código de conduta atualizado em 2014 e legislações correlatas, foram localizados e, por se direcionarem especificamente aos burocratas do Poder Executivo, foram incorporados no corpus de pesquisa. Por essa razão, considera-se fundamental ser flexível quanto aos termos buscados, pois os próprios documentos podem sugerir os termos mais adequados utilizados por arquivistas e/ou autores quando se discute determinado tema.

Quando se trata de considerar a "qualidade do serviço público", este termo oferece, em especial, maiores chances de inferir. Ressalta-se, neste ponto, a capacidade de compreensão do pesquisador em perceber que a ética não é só operacionalizada por um código de conduta instituído e fomentado por força de decreto presidencial, como também é relacionada com a qualidade com que os serviços públicos são prestados à população. Em termos de recortes de pesquisa, aqui se pode mudar os rumos a serem percorridos na investigação, pois, ao se identificar previamente o quão profícuo é se enveredar ou não por esse caminho, evita-se o dispêndio desnecessário de esforços.

Devido aos recortes estabelecidos, para o caso em tela, elege-se o Decreto n o 1.171 de 1994 como sendo o mais pertinente. Por óbvio, essa escolha não exclui a importância dos outros documentos localizados, por duas principais razões. A primeira é que, devido à capacidade de condensar outros documentos, o decreto os referencia e é considerado, sob esse ponto de vista, documento "mãe" de todos os outros até então localizados. Contudo, isso não impede que, ao se localizar outros documentos, estes possam não só mudar os rumos da investigação, como também assumir papel central em termos de ordem de relevância. A indução, neste sentido, deve ser observada.

A segunda razão se explica pela proximidade do processo de produção do decreto presidencial com o objeto de estudo, pois, considerando que o enfoque da investigação é institucional, essa espécie de documento representa, de modo mais direto, as intencionalidades e, por consequência, a interpretação sobre o conceito de ética no serviço público federal. Atrelado a esse ponto, explica-se também que a representatividade do documento escolhido (Lemos \& Souza, 2019) é elemento visceral da ADI, pois do que adiantaria empregar diversas técnicas de análise documental se ele não representa de fato o que se pretende estudar?

De forma adicional, se o decreto presidencial fosse, por exemplo, convertido no formato de vídeo e suportado em canal no Youtube, o pesquisador deveria apropriar-se dos comentários, curtidas de usuários ali tecidos e assegurar a representatividade através da análise do quantitativo de visualizações que o vídeo recebeu (Martínez-Ávila, Luvizotto, Brito \& Silva, 2020). Assim, é indubitável que o decreto eleito se alinha com o objetivo de pesquisa traçado, pois representa o conteúdo emanado pelo chefe do Poder Executivo aos burocratas em nível federal de órgãos e entidades da Administração Pública Federal direta e indireta.

Nesse contínuo, cumpre avaliar a credibilidade do decreto. Trata-se de produção discursiva decorrente de uma sistemática interação humana imersa no que se convencionou chamar de processo legislativo federal. 0 produto dessa interação é consubstanciado em texto e foi endossado, à época, pelo cargo político de maior hierarquia do sistema político brasileiro: o de presidente da República, ocupado por Itamar Augusto Cautiero Franco.

Alguns artefatos visuais, como o brasão oficial da Presidência da República e a assinatura do presidente, permitem assegurar a credibilidade do documento. Acrescenta-se, ainda, que um decreto presidencial é um documento que envolve o consentimento e o endosso da Casa Civil e da Subchefia para Assuntos Jurídicos. Logo, ao ser numerado, sua validação se concretiza com informações publicadas no Diário Oficial da União (DOU) na data de 23 de junho de 1994.

Para finalizar a preparação do material, é preciso considerar que, embora seja o último protocolo a se empregar, esta ordem não indica importância de esforços. Sendo assim, a compreensão do sentido da mensagem constitui imprescindível etapa na ADI. Em termos de utilidade, consta em paridade com o desenho da pesquisa como um todo, ao passo que indica o entendimento geral que se pode extrair do documento. Em essência, é válido indagar: quais sentidos o documento transmite? Quais mensagens e/ou intepretações ele induz? 
Em reposta a tais indagações, a partir da estrutura e raciocínio do texto, ao se trabalhar com polaridades positivo-negativas como justo/injusto, legal/ilegal, honesto/desonesto, indica-se que a ética é composta por elementos como legalidade e moralidade (princípios constitucionais) e também por justiça e honestidade. Isso significa que, na visão transposta pelo decreto, a face negativa desses elementos não pode ser revertida em face positiva com força de decreto presidencial. Ou seja, práticas consideradas imorais como, por exemplo, a utilização de linguajar vulgar (face negativa) quando do atendimento ao público não seria algo facilmente revertido em linguajar cortês (face positiva) por força de Decreto, ainda que presidencial.

\subsection{Fase 2: Análise Preliminar Ilustrada (API)}

Do mesmo modo que a primeira fase foi apresentada, a segunda também terá seus resultados demonstrados ilustrativamente. Quanto a essa ilustração, a Figura 4 a demonstra.

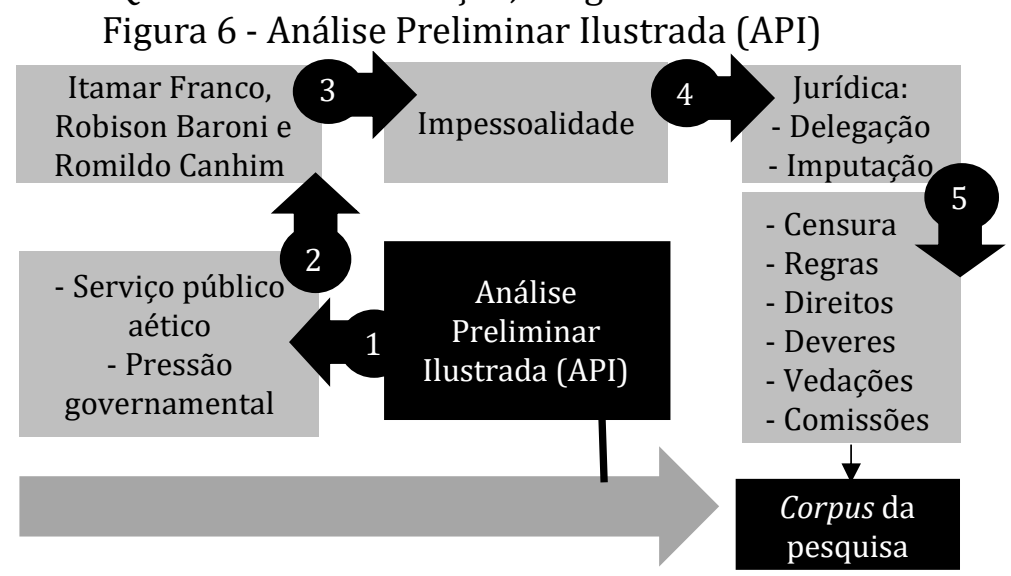

Fonte: Elaborada pelos autores.

Em explicação à Figura 6, no que concerne à dimensão do contexto, identificou-se que são dois os principais fatos que se apresentavam com certo vulto na Administração Pública na década de 1990. 0 primeiro foi a pressão exercida pela população de modo geral em relação à destituição de comissão parlamentar de ética pública, que gerou o questionamento popular sobre o real compromisso do governo de Itamar Franco com o combate à corrupção e à conduta dos ministros de governo. Nesse momento, alegava-se que os próprios ministros não tinham conhecimento do que viria a ser ética no setor público. Por essa razão, discutia-se a necessidade de o poder público responder a tal problemática.

0 segundo fato diz respeito à procedência dessas informações em que sua validação logra êxito por meio da observação de outros documentos publicados à época, como, por exemplo, artigos científicos. Nesse sentido, destaca-se a publicação de Robinson Baroni na Revista do Serviço Público em julho de 1994, cujo formato de ensaio teórico discutiu justamente o que viria a ser não somente ética, mas também moral no serviço público federal. Sobre este ponto, é importante ressaltar que tais informações não estão disponíveis no documento do Decreto $\mathrm{n}$ o 1.171 de 1994. Por essa razão, fica clara a importância de se buscar informações adicionais em jornais e revistas idôneas à época, conforme se procedeu na presente análise, em que as primeiras informações foram extraídas de notícia veiculada pela Folha de São Paulo no dia 24 de abril de 2006. 0 segundo fato que merece destaque é que o serviço público havia sido considerado, à época, aético ante as recorrentes práticas nepotistas e comportamentos personalistas.

Em se tratando dos autores envolvidos no processo de produção textual, é preciso seguir a recomendação de Costa e Silva (2019) de que, para se adotar a perspectiva integracionista do método documental, é importante buscar não somente os atores institucionais, mas também aqueles envolvidos de alguma forma no processo produtivo. Por essa razão, em excerto extraído da mesma notícia veiculada pela Folha de São Paulo, constatou-se que o professor Robinson Baroni, da Universidade de Taubaté (SP) -o mesmo que havia produzido o artigo científico supracitado, foi ator ativo no processo de concepção do decreto presidencial em exame. 
No entanto, isso não quer dizer que os atores institucionais não são relevantes na presente contextualização. Pelo contrário, é válido perceber que, após o decreto Presidencial, o próprio presidente Itamar Franco ficou conhecido como um "Presidente ético". Quanto à validação dessa afirmativa, há publicações em jornais e revistas como Exame, Globo e Veja, que tecem matérias com títulos como "Itamar Franco era polêmico, mas não cedeu à corrupção"; "Senadores destacam ética, coragem e firmeza nas posições do ex-presidente"; "A ética e a ousadia do presidente Itamar Franco" e "Governo Itamar Franco foi pautado por preceitos éticos". É preciso atentar-se também para o indivíduo Romildo Canhim, presidente da Câmara dos Deputados à época. Em primeira análise, cumpre salientar que este, na representação do Poder Legislativo, cumpriu nada mais do que a função de presidente da comissão parlamentar constituída para tratar do tema da ética no serviço público federal. Portanto, considera-se como um ator relevante nesse contexto de produção do Decreto $\mathrm{n}$ ำ 1.171 de 1994 .

Em termos de confiabilidade e autenticidade das informações supracitadas, observa-se que os meios de comunicação da década de 1990, em geral, não lidavam ainda com as chamadas fake news. Nesse sentido, é sensato dizer que as informações oriundas de notícias utilizadas na contextualização dos parágrafos anteriores são verídicas. No entanto, em se tratando das informações contidas no próprio decreto, é mister a afirmativa de que se trata de um documento pautado na construção textual em obediência ao princípio constitucional da impessoalidade, que preceitua a descaracterização de qualquer colocação valorativa no corpo textual do referido documento. Isso significa que o documento é confiável pelo fato de que não se tratou da opinião de apenas certos indivíduos, mas de uma problemática social tratada por um conjunto de indivíduos que têm legitimidade de representar toda uma sociedade. Por essa razão, inseriu-se o termo "legalidade" no quadrante "autenticidade e confiabilidade".

Quanto à natureza do documento, é notória sua estrutura jurídica. Isso porque traz em seu corpo textual termos como "delegação" e "imputação", por exemplo. Quanto a essa questão, salienta-se que, para que a próxima etapa de identificação dos conceitos-chave no texto seja exitosa, é imprescindível, de no mínimo, haver conhecimento prévio do significado desses termos jurídicos. Nesse esforço, sublinha-se que os conceitos-chave identificados no corpo do texto não foram esses dois supracitados. Na verdade, foi o de "censura". 0 significado desse conceito na lógica interna do documento, diferentemente do intuitivo, em nada se assemelha à tratativa de censura midiática que este recebeu no período da ditadura militar, por exemplo. Trata-se tão somente do ato de governo repreensível ao comportamento aético que se fez presente no serviço público federal. Por essa razão, a lógica interna do texto se estruturou no estabelecimento de direitos, mas também de regras a serem perseguidas por servidores públicos. Expressou ainda vedações e, quando preciso, o estabelecimento de comissões para que a censura pudesse ser aplicada ao servidor desertor.

\subsection{Fase 3: Análise Documental Ilustrada (ADI)}

Nesta terceira e última fase da pesquisa documental, será demonstrado ilustrativamente como se deu o preenchimento dos quadros do modelo proposto, a partir dos resultados da pesquisa. Quanto a essas informações, a Figura 7 as demonstra.

A tarefa de mencionar os fatos não se confunde com a mera descrição, pois, se assim fosse feito, a análise se enquadraria na classificação "suplementarista" cunhada por Costa e Silva (2019). Como este não é o objetivo da análise, é preciso ir além da afirmativa de que, em 1994, o serviço público federal foi considerado aético e que foi preciso que o presidente emanasse o Decreto n $1.171 \mathrm{em} 1994$.

Neste momento, a interpretação pode ser a de que o decreto foi utilizado pelo Presidente da República como força jurídica para contrapor o status quo do período. Isso significa que a medida de curto prazo a se tomar nesse sentido era a emissão de um decreto como forma de estabelecer regras para todos os servidores de uma única vez. Em síntese, corroborando com essa interpretação, constatou-se que havia certa incompreensão do que era permitido ou não se fazer no serviço público e, por consequência, do que era passível de censura. Nesse momento, o conceito de ética era incompreendido e enfrentava dissonância em sua operacionalização - por isso, a insatisfação popular com os burocratas do nível federal. Cumprindo com a tarefa de determinar tendências na presente análise, é sensato afirmar que a forma de Decreto Presidencial continuará sendo medida de curto prazo possível ao governo federal para conter intempéries na gestão de pessoal. Isso não só porque o Decreto $\mathrm{n}$ o 1.171 de 1994 continua vigente no país, mas também porque, em temáticas que tangenciam o tema "gestão de pessoal", novos decretos têm sido emanados. 
Figura 7- Análise Documental Ilustrada (ADI)

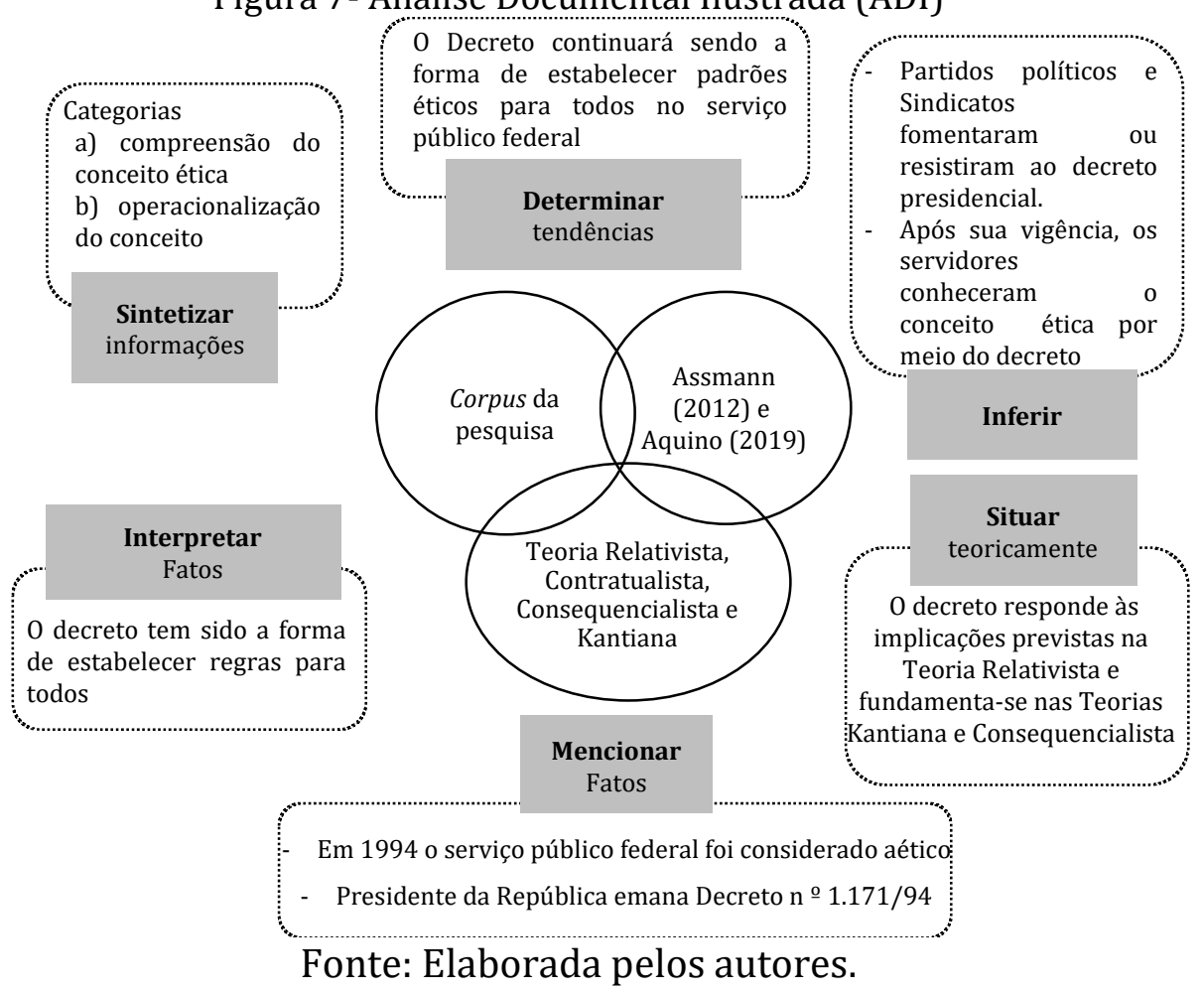

Já ao se empregar inferências, é possível refletir que grupos, como sindicatos classistas, representaram os interesses dos servidores públicos federais à época de 1990. Como se tratou de assunto que envolveu o parlamento brasileiro, também é possível inferir que partidos políticos exerceram a função de oposição durante a elaboração do decreto, o que, se comprovado, pode ter influenciado a estruturação e a própria lógica interna do texto.

Em última análise, ao situar teoricamente as informações empregadas na análise documental, afirma-se que a ética no serviço público federal correspondeu às implicações previstas na Teoria Relativista, Kantiana e Consequencialista. Isso se explica pela constatação de que os servidores públicos do governo federal decidiam por conta própria, na década de 1990, o que seria ética no âmbito de trabalho, revelando assim, o caráter relativo do que deve ou não ser aceito no serviço público federal. A resultantes deste relativismo engendrou a operacionalização do conceito ética a seu modo, resultando comportamentos não padronizados e, por óbvio, tornando-se mais tarde, em condutas repudiáveis pela população que recebia serviços do governo federal.

Por essa razão, o decreto presidencial foi utilizado como meio para se atingir o fim maior de tornar toda a ação humana padronizada eticamente e independente do desejo individual do servidor, que, sob pena de censura (Teoria Kantiana), operacionalizou-se sob a justificativa de que este era o melhor a se fazer, pois haveria consequências positivas para todos os que viviam em sociedade (Teoria Consequencialista). Portanto, a afirmativa de Assmann (2012) de que as normas sociais têm sido historicamente colocadas e validadas para todos os servidores públicos federais encontra congruência com os resultados apresentados e discutidos neste artigo. Em contraponto, embora haja a técnica da autoformação como mecanismo em gestão de pessoas para a construção de padrões comportamentais ressaltado por Aquino (2019), este não pôde ser identificado única e exclusivamente pelos documentos analisados neste caso ilustrativo. Sinalizam-se, deste modo, limites de inferência e fixação de tendências de estudos que fazem uso de uma pesquisa documental rigorosa, conforme preceituado ao longo deste artigo. Isso significa que um volume maior de documentos se faz necessário para que inferências e tendências se entrelacem em um percurso metodológico rigoroso. Embora o conceito de documento adotado neste artigo considere toda a construção discursiva suportada em distintos formatos, exclui "produtos acadêmicos", enfocando apenas em conteúdos documentais oriundos de atos da Administração Pública. Logo, contrasta com a significação assumida no estudo de Nunes, Simeão e Pereira (2020) e de Tete (2020), em que há uma concepção alargada da tipologia documental a ser incorporada no corpus de pesquisa, 
abarcando artigos científicos, dissertações e teses (o que se confunde, em certos termos, com o método de revisão bibliográfica). Sinaliza-se, então, essa distinção conceitual como um elemento diferenciador da proposta de sistematização de procedimentos para a Análise Documental Ilustrada (ADI) aqui colocada. Por outro lado, o estudo de Mastroianni, Vellosa, Malara e Leão (2019) revela que processos judiciais (tipologia essa não prevista neste artigo) também são documentos passíveis de serem compreendidos aos moldes da pesquisa documental, sinalizando, pois, a amplitude de documentos à disposição do pesquisador.

De modo adicional, confrontando a proposta deste artigo com a de Tete (2020), aponta-se não apenas a distinção ad hoc de área do conhecimento, mas, sobretudo, o complemento aos seis estágios cunhados pela autora. No primeiro estágio, a autora recomenda identificar o tópico a ser estudado e formular questões de pesquisa, recomendações essas não incorporadas em estágios da ADI propriamente dita, mas no momento da delimitação da pesquisa científica como um todo. No segundo estágio, ao propor genericamente o "questionar as fontes de pesquisa", a fase de Preparação de Material Ilustrada (PMI) considera não apenas a importância do questionamento das fontes, como também avalia, antes de tudo, potenciais fontes de informação, ao invés de coletar documentos para depois aferir a credibilidade da fonte. Explora, ainda, estratégias de busca, representatividade e compreensão do conteúdo documental já em fases iniciais da ADI, na PMI.

Já no terceiro estágio, Tete (2020) trata da seleção, avaliação da qualidade, confiabilidade, distinção de fontes e leitura preliminar, esforços esses também corroborados na PMI. No quarto estágio, recomenda a leitura em profundidade dos documentos, prevendo possíveis insights e novas possibilidades de pesquisas, movimentos esses também previstos pelas fases propostas neste artigo quando se afirmou que a finalidade pedagógica não se confunde com fases engessadas e rígidas. No quinto estágio, o processamento de informações assume a finalidade de trazer respostas coerentes e concatenadas teoricamente para a(s) questão(es) de pesquisa, aspecto que apresenta similaridade com o preceituado na PMI, diferindo-se, porém, quanto à importância de se traçar relações com as referências bibliográficas e documentos componentes do corpus de pesquisa e não apenas com teorias. Em última análise, porém não menos importante, ao preceituar a redação dos resultados como sendo o sexto estágio para a pesquisa documental, considera-se ser este um esforço óbvio a ser empregado com a finalização da pesquisa, embora seu "lembrete" se faça necessário.

Além do mais, embora o caso ilustrativo utilizado neste artigo tenha se utilizado de um documento normativo na forma textual, a proposta de sistematização de fases para a ADI rompe com a visão míope de que apenas documentos escritos são passíveis de incorporação no corpus de pesquisa, visão essa ainda persistente nos estudos organizacionais (Silva, Piurcosky, Calegário \& Benedicto, 2019).

\section{Considerações finais}

A questão de pesquisa levantada sobre como operar a pesquisa documental de modo coerente e concatenado pôde ser respondida ao se atender os critérios de qualidade de Phillips (2006). Assim, considera-se cumprido o objetivo deste artigo de contribuir com o processo de pesquisa (primeiro critério de qualidade) em Design Science Research (DSR). Ante o grau de sistematização oferecido ao processo de Análise Documental Ilustrada (ADI) em Administração Pública, o cumprimento do objetivo deste artigo não apenas se concretizou ao longo das fases de Preparação do Material Ilustrada (PMI), Análise Preliminar Ilustrada (API) e Análise Documental Ilustrada (ADI), como também lançou luz sobre a questão de "como?" o processo de pesquisa documental é passível de melhorias, por meio do caso ilustrado (significado de ética no serviço público federal), bem como dos cuidados sinalizados durante a Análise Documental Ilustrada(ADI). Atendeu-se assim, ao segundo critério de qualidade (explanar como o objetivo da pesquisa foi alcançado), pois, por meio do caso ilustrativo, ficam comprovados os limites de inferência e interpretação a se extrair de conteúdos documentais, conforme apurado no conceito de autoformação de Aquino (2019). Logo, essa constatação só foi possível em função da Análise Documental Ilustrada (ADI) demonstrada na Figura 7. Já no que tange ao terceiro critério de qualidade (know-how do pesquisador), salienta-se o contato prévio dos autores com o documento utilizado no caso ilustrativo.

Diante do exposto, e durante a consecução da pesquisa documental, a falta de informações claras sobre onde seria possível coletar dados e informações a respeito de temáticas de pesquisa constituíram entraves à construção do corpus de pesquisa. Isso se constatou quando comumente foi preciso recorrer 
a mecanismos mais robustos de buscas na internet, como o buscador Google, em que, a partir da utilização de operadores booleanos como "in", foi possível filtrar informações disponíveis em sites que ofereceram dados não disponíveis do decreto presidencial analisado.

Ressalta-se que, quando os documentos desejados não estiverem disponíveis em formato digital, o pesquisador deve conhecer as tabelas de temporalidade de sua guarda em bibliotecas ou bases de dados do governo que os armazenam. Sendo assim, recomenda-se que maiores instruções sejam buscadas junto ao Conselho Nacional de Arquivos (Conarq) e à Controladoria Geral da União (CGU), órgãos responsáveis por este tipo de informação. A intenção do artigo, em termos de finalidade pedagógica, foi contemplada para além da proposição sistemática da ADI, por meio de ilustração de natureza empírica, como a análise de um decreto presidencial para tratar da operacionalização do conceito de ética no serviço público federal brasileiro. Tal ilustração inclusive vai além da dimensão pedagógica, retomando princípios da Administração Pública e valores morais em sociedade, aplicáveis e extensíveis a outros contextos. No entanto, esse contributo não isenta este trabalho de limitações de pesquisa, sendo a análise de apenas um documento no caso ilustrativo proposto um aspecto limitador. É recomendável, portanto, considerar um maior volume de documentos, como, por exemplo, os decretos dos anos de 1999, 2002, 2003, 2005 e 2008 que mencionavam o termo "ética".

Em termos de validação do estudo, internamente considera-se que este foi alcançado por meio da aplicação em um caso concreto ilustrativo, porém, externamente, por não haver aplicação das fases propostas em outros contextos para além do aqui administrado, sinaliza-se outro aspecto limitador da pesquisa, o qual se espera superar com avanços futuros de novos estudos aplicados, inclusive em outras áreas para além da Administração Pública.

Embora não se afirme categoricamente que a verdade dos fatos situe-se apenas em documentos como normas e regulamentos, o tratamento que essa natureza documental recebeu ao longo do artigo foi como algo verdadeiro e "taken for granted", ou seja, dado como pronto e acabado, que emerge de fontes confiáveis e que, portanto, suporta uma ADI robusta. Adicionalmente, estimula-se o uso de documentos de natureza jornalística como estratégia de pesquisa para contextualizar o processo de produção de conteúdos documentais - não necessariamente normas e regulamentos. Não obstante, quando considerado um volume maior de documentos, suscitam-se reflexões quanto à possível triangulação metodológica com outros métodos de pesquisa, também não realizada neste estudo. Deste modo, vislumbra-se a Análise de Conteúdo de Bardin (2011) devido ao seu adequado grau de sistematização dos elementos demonstrados na fase 3 - (ADI). Por meio da categorização e subcategorização de informações tecidas a partir dos dados documentais levantados em etapas anteriores, possivelmente se empregará uma pesquisa documental robusta.

Quanto à possibilidade de triangulação metodológica, sugere-se investigar se novas etapas ou protocolos se colocam como necessários à sistematização proposta por este artigo. Por fim, a despeito das limitações e da menção de outras possibilidades de aplicação da pesquisa documental, reitera-se o contributo deste artigo em apresentar, a partir de um caso ilustrativo, uma proposta sistematizada de operacionalização da pesquisa documental como recurso para auxiliar ingressantes e interessados na sua (re)aplicação acadêmica enquanto método científico ou na sua replicação técnica diante das demandas organizacionais da área de AP, surgindo neste caminho, possíveis intersecções com a área da Ciência da Informação.

\section{Referências}

Allegretti, A. C. V., Moysés, S. T., Werneck, R. I., Quandt, C. O., Moysés, S. J. (2018). Redes Sociais na produção científica em Administração Pública da saúde no Brasil. Revista de Administração Pública, 52(4), 571-592. https://doi.org/10.1590/0034-7612162930

Almeida, J. L. S. (2015). A Biblioteca como Organização Aprendente: o desenvolvimento de competências em informação no Instituto Federal de Educação, Ciência e Tecnologia da Paraíba. (Dissertação de Mestrado em Gestão de Organizações Aprendentes). Universidade Federal da Paraíba, João Pessoa (PB), $123 \mathrm{p}$.

Amorim, V. M. V. (1994). A capacitação e a profissionalização do dirigente publico como componentes estratégicos de reforma administrativa (Dissertação de Mestrado). Fundação Getúlio Vargas (FGV), Rio de Janeiro. Recuperado de http://bibliotecadigital.fgv.br/dspace/handle/10438/8019 
Assmann, H. (2012). Reencantar a educação: rumo à sociedade aprendente (12 ed.). Petrópolis - RJ: Vozes.

Aquino, M. G. (2019). Noções de sujeito e poder em leituras foucaultianas e sua influência nos estudos de organizações e gestão de pessoas. Cadernos EBAPE.BR, 17(3), 448-459. Epub Agosto 22, 2019.https://dx.doi.org/10.1590/1679-395173587

Bardin, L. (2011). Análise de conteúdo. São Paulo: Edições 70.

Bax, M., \& C. Resende, L. (2020). A Curadoria Digital de Dados Científicos no Campo da Ciência da Informação. Perspectivas em Ciência da Informação, 25(especial), 233-251. Recuperado de http://portaldeperiodicos.eci.ufmg.br/index.php/pci/article/view/4306/2356

Bernardes, J. S., \& Menegon, V. S. M. (2007). Documentos de domínio público como produtos e autores sociais. Revista PSICO, v. 38(1), p.11-15.

Bezerra, D. M. (2011). Reformas administrativas no Brasil: o caso do governo do estado do Piauí (Dissertação de Mestrado). Universidade Federal do Rio Grande do Norte, Natal - RN. Recuperado de https://repositorio.ufrn.br/jspui/handle/123456789/18290

Brasil. Decreto ${ }^{\circ} 1.171$ de 22 de junho de 1994. Aprova o Código de Ética Profissional do Servidor Público Civil do Poder Executivo Federal e dá outras providências. http://www.planalto.gov.br/ccivil_03/decreto/d1171.htm

Bowen, G. A. (2009). Document Analysis as a Qualitative Research Method. Qualitative Research Journal, 9(2), 27-40. https://doi.org/10.3316/QRJ0902027

Carvalho, R. L. M. L. (2018). Evolução do Federalismo Político e Fiscal nas Constituições Republicanas (Dissertação de Mestrado). Universidade Federal de Viçosa, Viçosa - MG.

Cavalcanti, C. O. B. (1995). Impactos da reforma administrativa do governo Collor na modelagem organizacional do DNER (Dissertação de Mestrado). Fundação Getúlio Vargas (FGV), Rio de Janeiro. Recuperado de http://bibliotecadigital.fgv.br/dspace/handle/10438/7938

Cellard, A. (2008). A análise documental. In A pesquisa qualitativa: enfoques epistemológicos e metodológicos (3 ed.). Petrópolis: Editora Vozes.

Corrêa, V., Trottmann, P., Coelho, F. D. S., \& Sarti, F. M. (2017). A Produção Científica em Administração Pública e Políticas Públicas no Brasil: Evidências de Proximidade e Similaridade no Período 20002010. Revista Eletrônica Gestão e Serviços, 8(2), 2127. https://doi.org/10.15603/21777284/regs.v8n2p2127-2146

Conselho Nacional de Arquivos (2014). Criação e desenvolvimento de arquivos públicos municipais: transparência e acesso à informação para exercício da cidadania. Rio de Janeiro: Arquivo Nacional, (151 p.) ISBN: 978-85-60207-29-9

Costa, A. S. M., Barros, D. F., \& Martins, P. E. M. (2010). Perspectiva Histórica em Administração: novos objetos, novos problemas, novas abordagens. Revista de Administração de Empresas, 50(3).

Costa, A. D. S. M., \& Silva, M. A. C. (2019). A Pesquisa Histórica em Administração: uma Proposta para Práticas de Pesquisa. Administração: Ensino e Pesquisa, 20(1). https://doi.org/10.13058/raep.2019.v20n1.1104

Cremaschi, S. V. M. (2007). Il Relativismo Ético Fra Antropologia Cultural e E Filosofia Analítica. In I. Tolomio (Org.), Rileggere l'etica tra contingenza e principi (p. 15-46). Padova, Italy: CLUEP.

Cunha, J. A. C, Yokomizo, C. A., \& Bonacim, C. A. G. (2014). Miopias de uma lente de aumento: as limitações da análise de documentos nos estudos das organizações. Revista Alcance, 20(4(Out-Dez)), 431-446. https://doi.org/10.14210/alcance.v20n4.p431-446

Dewey, J. (1971). How we think: A restatement of the relation of reflective thinking to the educative process. Chicago: Henry Regnery Co

Dresch, A., Lacerda, D. P. \& Antunes Júnior, J. A. V. (2015). Design Science Research: método de pesquisa para avanço da ciência e tecnologia. Porto Alegre: Bookman.

Flick, U. (2009). Introdução à pesquisa Qualitativa (3 ed.). Porto Alegre: Artmed.

Garcia, A. S., Pereira, J. R., Alcântara, V. C., \& Prado, J. W. (2019). Produção Científica sobre Esfera Pública: um Estudo Bibliométrico em Múltiplas Áreas do Conhecimento (1970-2015). Administração Pública e Gestão Social, 11(1), 2-15. https://doi.org/10.21118/apgs.v11i1.1650

Garcia, M. O., Rodrigues, P. E. L., Emmendoerfer, M. L., \& Gava, R. (2016). Usos da Pesquisa Documental em Estudos sobre Administração Pública no Brasil. Teoria e Prática em Administração, 6(1), 28.

Gonçalves, J. (1998). Como classificar e ordenar documentos de arquivo (Vol. 2). São Paulo: Arquivo do 
Estado.

Gonçalves, T., \& Varella, M. (2018). Os desafios da Administração Pública na disponibilização de dados sensíveis. Revista Direito GV, 14(2), 513-536. http://dx.doi.org/10.1590/2317-6172201821

Hepworth, M. (2014). Research and practice: A critical reflection on approaches that underpin research into people's information behaviour. Journal of Documentation. 70. 1039-1053.

Hevner, A.R. (2007). A Three Cycle View of Design Science Research. Scandinavian Journal of Information Systems, 19, 4.

Ikeda, A. A., Veludo-de-Oliveira, T. M., \& Campomar, M. C. (2005). A tipologia do método de caso em Administração: usos e aplicações. Organizações \& Sociedade, 12(34). Recuperado de https://portalseer.ufba.br/index.php/revistaoes/article/view/10796

Kant, I. (2006). Crítica da Razão Prática. Trad. Antônio Carlos Braga (Vol. (Coleção Grandes Obras do Pensamento Universal). São Paulo: Escala.

Lemos, D. L. S., \& Souza, R. R. (2019). Ontologias na representação de documentos: um panorama atual para descrição de conteúdo multimídia em rede. Informação \& Sociedade: Estudos, 29(4), 103-134. Recuperado de https://periodicos.ufpb.br/ojs2/index.php/ies/article/view/47421

Lopes, B., \& Rodrigues, G. (2019). Os acervos privados de presidentes da República no Brasil. InCID: Revista De Ciência Da Informação E Documentação, 10(1), 64-80. https://doi.org/10.11606/issn.21782075.v10i1p64-80

Lüdke, M., \& André, M. E. D. A. (1986). Pesquisa em educação: Abordagens qualitativas (3 ed.). Editora Pedagógica e Universitária EPU.

Martínez-Ávila, D., Luvizotto, C., Brito, J., \& Silva, R. (2020). Disseminação, compartilhamento e apropriação da informação no Youtube: uma análise do canal LGBTQ "PÕE NA RODA". Encontros Bibli: revista eletrônica de biblioteconomia e ciência da informação, 25, 01-18. doi:https://doi.org/10.5007/15182924.2020.e67718

Mastroianni, F. C, Vellosa, F. R. F., Malara, L. C. M, \& Leão, A. M. C. (2019). Alienação parental em processos judiciais. Revista Internacional de História Política e Cultura Jurídica, 11(3) 488-508.

Miranda, W. S. (2014). Foucault e a questão do sujeito: as tecnologias do eu e a criação de novas subjetividades. Fenomenologia e Psicologia, 2(1) 19-34.

Moraes, S., Almeida, C., \& Alves, M. (2020). Informação, Verdade e Pós-Verdade: uma crítica pragmaticista na Ciência da Informação. Encontros Bibli: revista eletrônica de biblioteconomia e ciência da informação, 25, 01-22. doi:https://doi.org/10.5007/1518-2924.2020.e65505

Morris, D., \& Ecclesfield, N. (2011). A new computer-aided technique for qualitative document analysis. International Journal of Research \& Method in Education, 34(3), 241-254. https://doi.org/10.1080/1743727X.2011.609547

Nascimento, M. (2011). Jean-Jacques Rousseau: os princípios do Direito Político e a História. Discurso, 41(41), 47-76. https://doi.org/10.11606/issn.2318-8863.discurso.2011.68365

Nunes, D. B., Simeão, E., \& Pereira, O. (2020). A prática da pesquisa documental em Psicologia. Revista Ibero-Americana De Ciência Da Informação, 13(1), 339-359.

https://doi.org/10.26512/rici.v13.n1.2020.29608

Phillips, D. C. (2006). Assessing the quality of design research proposals: some philosophical perspectives. 144-155. In: Akker, J. V. D, Gravemeijer, L., McKenney, S. \& Nieveen, N. (Org) (2006). Educational Design Research, Netherlands: Routledge.

Popper, K. R. (1974). Objective knowledge: An evolutionary approach. London: Oxford University Press. Reichenbach, H. (1938). Experience and prediction: An analysis of the foundations and the structure of knowledge. University of Chicago Press. https://doi.org/10.1037/11656-000

Salminen, A., Lyytikäinen, V., \& Tiitinen, P. (2000). Putting documents into their work context in document analysis. Information Processing \& Management, 36(4), 623-641. https://doi.org/10.1016/S0306-4573(99)00070-9

Sá-Silva, J. R., de Almeida, C. D., \& Guindani, J. F. (2009). Pesquisa documental: pistas teóricas e metodológicas. Revista Brasileira de História, 15.

Schultz, J. P. (2018). Internacionalização da Educação Superior No Brasil: A mobilidade estudantil em uma Universidade Federal Mineira (Dissertação de Mestrado). Universidade Federal de Viçosa, Viçosa - MG. 
Silva, L. L., Costa, T. T. M., \& Nobre, L. L. C. (2014). Análise da produção científica em administração sobre a previdência brasileira: meta-avaliação da produção nos eventos da Anpad. Revista Administração: Ensino e Pesquisa, 15(4), 769-804. https://doi.org/10.13058/raep.2014.v15n4

Silva, M. R. (2017). História organizacional da ENAP: uma análise dos papéis desempenhados e das competências desenvolvidas (Tese de Doutorado). Universidade Federal da Bahia, Salvador - BA. Recuperado de http://ri.ufs.br/jspui/handle/riufs/2072

Silva, S. W., Piurcosky, F. P., Calegário, C. L. L., \& Benedicto, G. C. (2019). Pesquisa histórica e documental como práxis nos estudos organizacionais, Espacio Abierto 28(4), 202-212.

Simão, J., \& Rodrigues, G. (2006). Acessibilidade às informações públicas: uma avaliação do portal de serviços e informações do governo federal. Ciência da Informação, 34(2). Recuperado de http://revista.ibict.br/ciinf/article/view/1093

Tenaglia, M., \& Rodrigues, G. (2020). Negação, ocultamento e (falta de) gestão documental: o acesso aos arquivos nos relatórios finais das comissões da verdade no Brasil. Informação \& Informação, 25(1), 276-301. doi:http://dx.doi.org/10.5433/1981-8920.2020v25n1p276

Tete, C. (2020). La recherche documentaire em soins palliatifs. Médecine palliative, 1(19), 24-28. https://doi.org/10.1016/j.medpal.2019.09.004

Vieira, F. S. (2018). Curso de Processo Legislativo. Brasília: DF.

Wieringa, R. (2014). Design science methodology: for information systems and Software engineering. New York: Springer. 